\title{
1. The merchant and the common good: social paradigms and the state's influence in Western history
}

\section{Agustín González Enciso}

\subsection{INTRODUCTION}

The 2013 symposium that was the first seed for this chapter had a thought-provoking title: 'The Challenges of Capitalism for the Common Good'. This calls for a definition of capitalism itself and also of the common good. From a historical point of view, capitalism is understood as the development of the monetized economy and commerce outside the feudal agrarian economy. This might, prima facie, seem simplistic, but it does give us a basic handle on capitalism, including as it does the slow but steady ousting of an exclusively agrarian-based economy (González Enciso, 2011). The idea of the 'common good', for its part, implies that people are persuaded of the need to work for the benefit of the whole community, striking a balance between individual rights and obligations towards the rest, towards the community.

The problem for us is that both the community itself and the question of what should be done in its favour have been understood differently down the ages. In the two economic models - agrarian-based and commerce-based - the idea of the common good itself and the social and economic agents underpinning it are quite different. So, too, are the institutions and mindsets; all this will change as capitalism develops (Piettre, 1955). In the feudal economy the concept of community precedes its legal definition. The subsequent tripartite structure was the best way found for organizing the community (Duby, 1978). Individuals simply had to accept the social role assigned to them. Under capitalism, on the other hand, the idea of community is defined chiefly by a state embodying the whole social structure, and the task of each individual can be reduced to seeking his own best interest, albeit obeying the king. The difference is therefore great. 
The common good always used to be understood through an ethical prism including care for others: benevolence (bene volere, to want the good for the other). Since Adam Smith, however, the merchant's ethic of private interest has been understood as opposed to benevolence (Lázaro Cantero, 2002, p. 252). Self-interest was sufficient.

Was it ever thus? Did the mercantile ethic always see private interest as excluding benevolence? It is true that merchants of all times have tended to seek their own best interest, but it is no less true that, throughout history, the concept of private interest had always been understood within a social context. What we see, then, is a change in the understanding of mercantile ethics in accordance with the social context. The point here is: which social context is in question and who defines it? This chapter tries to develop the idea that merchant's ethics - or professional behaviour depended on social paradigms, and that change of those paradigms depended on the influence of royal or state power.

In general terms, until the fifteenth century the social context was a feudal society with feeble royal power, where the legal definition is given a priori by the laws of the privileged structure of the three estates, the time-honoured tradition onto which Christian morality had been grafted. From the fifteenth to sixteenth century onwards, however, the increase in royal power ushered in not only different social relations but also a different conception of morality in all its aspects, changing the ruledefining authority, with the king sitting at the top of the pile. The French Revolution would change things again, giving priority to individuals. Since the outcome of all that seems to be mere individualism devoid of social concerns, we need to look at the relations between individualism and the common good, and how they have evolved over time.

\subsection{THE MEDIEVAL PERIOD UP TO THE FIFTEENTH CENTURY}

How was the concept of the 'common good' and individualism understood in the tripartite order?

\subsubsection{Functions and Privileges: A Theory}

The society of estates was a corporate society in which each individual slotted into a more or less inclusive social grouping that moulded his or her identity. It was a society of functions: each estate - clergy, nobility and commoners - was assigned a social function (Oratores: 'those who pray'; Bellatores: 'those who fight'; and Laboratores: 'those who work'), 
and all individual members were duty-bound to fulfil their part of the assigned function. Accordingly, it was a society of privileges, of private laws different for each social grouping, enforced according to the estate concerned and giving a different social status in each case. This meant that the action of individuals was limited by their own privileges and by those of the rest.

This functional division was geared towards the fulfilment of a given purpose, the common good, defined in community-based terms: the common good is the good of society as a whole, both material and spiritual. Each individual, within the social grouping he/she belonged to, participated in the generation of this common good on the basis of fellow feeling with the rest. How were these privileges defined? Who defined their mutual fit? The division stemmed from a long historical tradition, first defined in early feudal times and theoretically established in the thirteenth century (Rodríguez Casado, 1981; Evangelisti, 2009).

\subsubsection{The Practice}

In practice, accession to a privileged status was different in each case. The clerics were selected by clerical authority, the nobles were created by the king who bestowed on them privileges and political jurisdictions, as he did also to church institutions and cities. These three groups (clergy, nobles and cities - cities meaning merchant interests) made up the representative institutions, the parliaments. From the thirteenth century they controlled the political power of the king in order to guarantee the common good. But from that same time onwards, kings nevertheless steadily increased and cemented their power bases, producing in time kingdoms that were more centralized and organized than hitherto. This has led to the moot notion of the modern state (Strayer, 1970).

As the power of the king was increasing, the limit of the functions of each estate was decided by the political balance struck at each moment. In the case of the nobles and ecclesiastical lords, the result was their ascription to the political power of the king, while they hung on to their jurisdictional power: social and economic power over their vassals. There were no longer private feuds between nobles, and many of the king's closest advisors no longer came from the noble class. That was the situation in around the 1480s.

\subsubsection{The Merchants and the King}

What was the merchant's ethical position within the tripartite order? What were his evolving relations with the king? The merchant was 
entitled to seek his own interest, and in fact he did so but always within the limits allowed by his own set of privileges and those of the rest. The watchword of the fourteenth-century merchant Francesco di Marco Datini, Prato, was: 'for God and for the money' (Origo, 1963). The merchant had to earn money; it was permissible to do so, but always within the range of civic and religious rules, including a respect for the privileges of each estate (Puigarnau, 2002; Le Goff, 2012).

But according to political facts, the merchant's ethical stance had an ongoing development: the medieval merchant was beholden to his family, his firm and his city; this marked the horizon of his sense of common good and fellow feeling. Little by little, however, the merchant's function was also allied to the king's power in so far as the king was willing to legislate on mercantile activity (Mitre, 2013).

\subsubsection{The Idiosyncrasy of the Mercantile Function}

Before going further, we need to look at the idiosyncratic aspect of the merchant's function within the estates. In the tripartite order the function of the nobles, clergy, and of the peasants and artisans was pretty well defined. The privileges ring-fenced their activities fairly clearly among themselves and vis-à-vis the king.

The merchant's function, on the other hand, was not so well defined because it is difficult to ring-fence commerce. It is pretty facile to say that merchants should do business and provide society with its wherewithal, but who decides which goods are needed, which are surplus to requirements, how and where they should be bought or sold and at what price? At the end of the day all these decisions were taken by the merchants themselves, and for a very simple reason: only the merchant could make these decisions with any sense of precision or certainty. His professional expertise gave him access to information denied from the rest because they had never crossed the borders of their home kingdom; their ignorance of any distant matters was absolute. If it was difficult to confine the merchants within their own kingdom, how much more difficult was it to control them within the laws of different, remote or even enemy countries ruled by other cultures and religions?

Even within the tripartite order, therefore, the merchant had a particularly individualist ethical stance (Aurell, 2002): first, because caring about others does not preclude one's own self-interest, but, from a more practical point of view, because only he was au fait with the world of trade. If it was difficult to define his functions with any precision, then it was no easier to define his ethical norms. This was not because morals did not matter to merchants. They did: it was simply because it was 
difficult to define the morality of their acts due to ignorance of the terrain in which they worked, that is, the real nature of merchant transactions.

What remains unclear is not the function per se but its limits, the rules applicable to many of its most arcane aspects. Commercial and financial techniques are at times complex and it is difficult to see what lurks behind them. All this gives a certain freedom to the merchant - not the freedom to do as he likes, but certainly greater leeway within a field of little-known activities and freer decision-making. It is true that markets were increasingly regulated in the medieval period, making it possible to objectively improve exchange activities (Vázquez de Prada, 1999); but at the same time markets expanded and reached areas of uncertain legal control.

\subsubsection{Scholastic Principles of Trade Morality}

The difficulty of defining the morality of the merchant's actions directed the attention of moralists to the need to define principles of action. So scholastic theologians devoted themselves to studying economic acts. To be able to come to some judgement on the morality of these acts, it was first necessary to determine their nature. The theologians thus delved into the nature of commercial and financial techniques to ascertain their moral legitimacy: for example that the agent's intention does not exclude the common good; that the profits were fair and the real fruit of work done; that no third parties should be injured; that delays should be compensated; and so on.

From the twelfth to the sixteenth century, above all, the theologians gradually phased in permissible exceptions to the time-honoured general prohibitions. Scholastic thought made a magnificent contribution to economic theory (Grice-Hutchinson, 1952); indeed, the first great theoreticians of the economy were the scholastic theologians of medieval Europe, followed by the sixteenth-century Spanish thinkers of the school of Salamanca (Chafuen, 1986). This laid the foundations of economic theory and its ethical bases (Stark, 2005). What emerges from these studies is a positive, active and free vision of economic action that blends the general interest, the common good, with private interests (De Roover, 1948). All this shows that the late medieval merchants had a strong moral compass to go with their profit motive, 'for God and for money'. As Sombart (1972, p. 164) put it, they loved business but they loved life also; 'life' here means all non-economic interests (Murray, 2010). 


\subsubsection{Pre-mercantilism: Who Rules over Trade?}

Be that as it may, neither the religious moral rules nor the opinions of the theologians had any coercive force. The main practical development in the late Middle Ages was an increase in royal legislation, which gave a nod towards theological concerns while seeking to benefit the realm. This phase has been dubbed by some authors 'pre-mercantilism' (Deyon, 1969). The economic expansion of the fifteenth century tended to merge the interests of kings - always strapped for cash - with merchants and trading cities. It has even been suggested that a pact was set up between them, but this is merely a manner of speaking. Barring some one-off agreements, it was rather a question of specific measures and attitudes by which late medieval kings fomented the trade that gave them a twofold benefit: the wealth brought into the kingdoms on the wings of this trade and, above all, the revenue creamed off by the customs.

Quite some time before colonial expansion, therefore, a protomercantilism was sketched out, embracing an inchoate economic nationalism, controlled and led by the king, whose main agents and beneficiaries were the merchants and, on a broader scale, businessmen as a whole, whose role and remit were strengthened from the fifteenth century onwards. They spawned the kings' great lenders (Medicis, Fugger), who catered for spiralling overseas and military political needs (Parker, 1989), which stood in need of a healthy economy that the kings also tried to foment.

So where does the common good now stand in all this? In the Middle Ages, merchants had set their ethical compasses according to the suggestions of the theologians, who helped to define the nature of the acts and, ipso facto, their morality. But the kings, juggling concerns for morality with the need to boost the nation's wealth and the royal revenue, had been moulding all those theoretical and practical suggestions into laws, more or less biased towards their political interest (Bernal, 2005). But our concern now is not so much the shrewdness or otherwise of the kings, but the fact that this legislation put flesh on the bones of what can be seen as an incipient economic nationalism. It should also be borne in mind that due to the fact that kings were consecrated and all believed that power comes from God, the king represents in this respect the will of God, so obeying him was more than a simple civic act.

\subsubsection{Towards Confessionalism}

The result for the merchant was that the situation had changed. Back in the thirteenth century, merchants had to check the legitimacy of their 
actions against the counsels of their confessors; in the fifteenth century they had to worry only about obeying the king. On the one hand, royal laws bound them to act in a certain way; on the other, they could help them to boost economic wealth; in the last analysis there was an implicit moral guarantee. What if the moral rule and the king's rule should come into conflict? Then the problem was the king's, not the merchants'. Royal laws impinging on the economic sphere did not always chime with the opinions of the theologians (Bernal, 2005); in cases where the political will was particularly firm, however, the king could always find an obliging theologian to back him up.

The early modern era brought in a counter-intuitive change: the early modern monarch has a greater religious authority than the medieval monarch. The reason lies in the lesser separation of these spheres in the early modern period. In medieval times, politics may seem at first sight to be very close to the Church, but in fact the bishops wielded quite enough influence to keep the kings in line and avoid any encroachment on church activities. In the early modern age, on the other hand, this did not happen. The theory of absolutism placed even more emphasis on the king's religious authority, whereby the monarch, defending in turn religion more than beforehand (effect of the religious division of the Reformation), acquired a power he previously lacked and managed to control religious institutions through regalism and patronage.

All the above is meant to show how an ethical transposition was generated over time in the mercantile mind. Morality no longer consisted necessarily of obeying the theologian, but only of obeying the king. The increase in royal power, notable at the end of the fifteenth century and especially in the sixteenth, explains this choice perfectly. Religious changes of the time, moreover, all tended to increase the king's preeminence over the theologians in the social order. This occurred not only in the reformed churches, but also in those that remained Catholic, by means of the monarchs' regalist policies. Confessionalism implies a politicization of faith and, ipso facto, of ethics. Hereafter moral norms would come from the king, doubling as a religious authority.

\subsubsection{On the Freedom of the Merchants in the Society of Estates}

An interesting question we can ask now is: what sense can be made of freedom in the tripartite order? The answer is: the possibility of acting without let or hindrance within the particular sphere of entitlement. Freedom, in other words, was not then understood as a utopian absolute, the power of acting completely at will; rather, it was consistent with the obligations incumbent on each social agent (González Enciso, 2009). 
Freedom is the necessary condition for complying with a responsibility and assuring such rights as may be held in each case. By the end of the fifteenth century, the merchant's leeway for action was already large and was also vouchsafed by the king, first through his laws, which protected trade, and second through his conquests, which increased the scope for action. The merchant's leeway for action grew in line with the king's power. True, this leeway had a limit, marked by traditional privileges of landlords and guilds, for instance; but little by little these limits were offset by the widened horizon of the new mercantile world opened up in the Atlantic. This is why mercantile freedom, just like urban freedoms, was increasingly identified with the king.

\subsection{EARLY MODERN TIMES: CAPITALISM VERSUS THE MARKET ECONOMY IN THE SIXTEENTH CENTURY}

The sixteenth century is particularly interesting for our purposes here, not only because there was an ongoing growth of the population, the economy and mercantile opportunities, but also because the king's needs grew too, with a concomitant change in political ethics (Machiavelli and the reason of state), partly in response to these needs.

It was at this moment, the sixteenth century, when Braudel's distinction between the market economy and capitalism came into its own (Braudel, 1985), a distinction that directly impinges on the questions we are dealing with here. The development of the market's laws had favoured the growth of the market economy, even on an international scale; but capitalism was something else: it is an activity that goes beyond the legal limits. In what way? Braudel moots a market economy that we might dub 'ethical'. He does not use this word himself, but he does refer to the presence of established rules. This is tantamount to what E.P. Thompson called the moral economy of the crowd (Thompson, 1974) applied to the markets; it is what we have interpreted here as the possibility of acting within the sphere of recognized rights. There is therefore a sizeable proportion of the mercantile profession that works with an ethical attitude, respecting the established mores and customs handed down from the Middle Ages and now guaranteed by the king. These rules oil the wheels of the market economy. A classic and well-studied example is that of Simón and Andrés Ruiz, of Medina del Campo and Nantes (Lapeyre, 2008). 
But there is another part of economic activity that slips the leash of these rules. This activity is not new in the sixteenth century, but is now blessed with more opportunities. For activities of this type, or for the merchants who practise them, ethics begins to have another gauge, both broader and slacker. Braudel's example for differentiating between the market economy and capitalism in the sixteenth century does not correspond to colonial trade, already developed, or to exotic products, but to the inland cereal trade. It concerns the exporting merchant who looks for the best prices by dealing directly with the peasant seller instead of buying wheat on the local market. It should be pointed out here that, in the sixteenth century, in Castile as elsewhere, a maximum wheat price called the tasa had been established in an attempt to iron out fluctuations and protect the poor from the worst of them.

The attitude called by Braudel 'capitalist' is precisely this one of by-passing the law and seeking out new negotiation channels to improve the merchant's position. From this viewpoint the capitalist attitude cannot be understood exactly as a transgression of the ruling civic law, which did not achieve blanket coverage of all possible aspects of the mercantile life, but as a way to avoid this law; it is, we could say, to act on the other side of the law. Nevertheless, it can be a transgression of religious law since that attitude implies a position of advantage for the merchant over the peasant seller. These merchants, then, began to feel that their private interest might not chime with the general interest, that the general interest was conceived from a more blinkered economic viewpoint. They, on the other hand, were able to find profits beyond the limits of the law. Later on they asked for the king's blessing on these actions.

According to the terminology used by A. Piettre (1955), this attitude marks the change from a subordinated, law-abiding economy to an emancipated economy, seeking to be independent of morality-based laws - not because of disdain for morality, but because of a new conception of it: morality based on social convention more than on religious belief, albeit not removed from religion. Those changes will be completed by the seventeenth century.

\subsection{THE CHANGES OF THE SEVENTEENTH CENTURY}

\subsubsection{Mercantilism}

The development of the colonial world, already in full swing by the seventeenth century, created a seedbed for the spreading of these attitudes 
among many merchants of many different countries. Mercantilism came to full fruition in a much more highly evolved context of royal power that has been called absolutism. The king now governed everything, or tried to do so (Beik, 1992). Commerce in particular had been brought under meticulous royal regulations. The mercantile ethic, therefore, is no longer understood as an objective religious ethic; it is now governed solely by a political ethic, understood as the degree of mercantile freedom offered by the king himself, tailored to the particular circumstances of each realm. Each merchant is perfectly free, if he wishes, to observe the moral rule of his own particular religion, but he must also obey the king's law, albeit on the understanding that there will never be a great discrepancy between them, since the monarch also enjoys a sacred authority.

This sacred authority of the monarch is strengthened throughout the whole early modern era as power of the king over the churches, and also gives the king a footing for intervening in religious matters, since they were also now part of his remit: from this point of view, this has been dubbed the confessional era. To pronounce on ethical questions in commercial matters, in particular, the authority of the king and his courts stood in for the former religious authority, now increasingly called into question even in the Catholic world (Kessler, 2007). It therefore makes little sense to oppose a Protestant ethic to a Catholic ethic in commercial matters, since the rules were no longer dictated by the Church, and theologians tended to be given short shrift in the seventeenth century. In any case, what became increasingly possible now was a growing chasm between a personal religious ethic and the legal rules and social conventions when these no longer chimed with the former (Groethuysen, 1981; Clark, 1998).

The early modern era can be seen as the time when many things increased (population, markets, opportunities, etc.) and the everyday rules of living together changed, as well as their underlying philosophical justification: to this extent the early modern era can also be seen as a time of broadening ethics, or rather the growing possibility of applying ethics to new fields. Given that this amplification occurred in a context of religious and political division, it not only brought about confusion but also obliged everyone to create with some urgency a new ethic that might satisfy the new perspectives and situations, the new benchmarks.

\subsection{2 'L'Honnête Homme'}

This is the case, for instance, with the debate about passions. As Hirschman concluded, passions were considered dangerous precisely because they were passionate, so they needed to be tamed by something 
more objective, which was interest (Hirschman, 1977). Chiming with these zeitgeist ideas were the arguments put forward in Catholic France by the Jansenist writers. In practice, these theoretical questions came about with the concept of 'L'honnête homme' (Faret, 1630). The idea in all cases was to strike the right balance between the demands of the soul and the demands of society. All this was meant to avoid excesses, even in virtue. But achieving this ideal of moderation meant creating a new ethic. This ethic will also affect trade and prompt the merchant to adopt a middle ground between uprightness and selfishness, or enlarge, quite cynically, the scope of uprightness. It is what Groethuysen called the bourgeois conscience.

All this bears a relation to the great social change brought about by the kings' political action, calling the inherited tripartite order into question and shedding doubt on its social usefulness. The seventeenth century is the time of the royal courts, symbolized in royal palaces like Versailles (Burke, 1994). All social conventions, such as the bourgeois conscience, were closely connected with political correctness. The bourgeois aimed to reach court influence since all patronage, and all trading opportunities, came from there. More than ever before, the king ruled over trade.

\subsubsection{The Crisis of the Functions of the Estates}

In their actions to improve power and take centre stage, the kings modified the function of the estates. They changed the function of the nobility by bringing it under regal control and recruiting it into the project of a new state under royal direction. Into its governments and bureaucracies the kings also called people who were not of noble origin, while also organizing new standing armies that were no longer based on the nobles' armed vassals (González Enciso, 2013). The nobles' traditional function of government and military aid thus disappeared.

Meanwhile the kings stood in ever greater need of merchants for raising money and bringing in the taxes that were to swell state coffers. Mercantilism became, de facto, a state economy in which merchants were the cornerstones. In some cases, as in England and Holland, they received more freedom of action because this was what the kings wanted and needed, according to their own relative situation, especially in colonial trade. In other cases, like Spain, mercantile activity was regulated in the form of monopolies and other privileges because the kings understood this to be the best way of achieving the economy's ends.

In any case, what is really important for our purposes here is the fact that, by these actions, the kings not only increased their real power but 
also refashioned the traditional idea of the common good. Social organization ceased to be a common concern in which all sought the necessary balance that would guarantee fulfilment of their own particular remits. Society, rather, became the king's field of action and power, supposedly a rational action (Monod, 2001). The king became the sole guarantor of social organization and only he was really cognizant of what society needed. The king became the hub of the action: a sun king (that is, Philip III of Spain); 'l'État c'est moi' (Louis XIV of France), at least in the consideration of all the rest, as intended by the propaganda.

Within this perspective the tripartite order changed in actual practice. Although the estates still existed, the governments' objectives were no longer to guarantee the privileges of favoured groups and demand that they carry out their functions; rather, these governments now saw everything through the prism of strengthening their own activity. In doing so, the kings were continually riding roughshod over privileged ground. This was not only stoking up a future revolution (the revolt of the privileged), but was also pulling the rug from under the tripartite order, creating a new political-administrative scheme without completely derogating existing privileges.

\subsection{FURTHER EIGHTEENTH-CENTURY DEVELOPMENTS}

The upshot of all this was a new ethical scenario in which the social role of the agents changed. Merchants interpreted this as the possibility of increasing individualism, since this, in essence, was what the king was demanding of them: boosting trade and business activity, and personal enrichment, and all they were asked for in exchange was to pay their dues. The merchants' new ethical framework, in other words, was reduced simply to obeying the king, working and paying their taxes. They were also entitled to ask the king for legal and military defence of their mercantile activity, something the king was delighted to do. In short, during the seventeenth and eighteenth centuries there was a growing union of interests between kings and merchants, to the extent that kings had an interest in increasing trading activity. As an example, in France the traditional merchant courts (jurisdictions consulaires) were not dismantled with the Revolution, as were all other traditional institutions; they were organized from the beginning, with the king's approval, for the benefit of commerce (Kessler, 2007).

It could therefore be argued quite cogently that, together with a raison d'État that extolled the king's political power against all comers, a raison 
d'entreprise was also built up, which extolled the ethic of mercantile profit, quite simply, above any other ethical rule, with the only proviso that it should prove useful to the state. Judged from this viewpoint, old economic institutions such as those tied in with the privileges of landlords or guilds were dismissed as unfair and obsolete, in so far as they came across as obstacles to free trade, an idea that would be spread by physiocrats from the mid-eighteenth century as a sine qua non of growth in the nation's wealth. The nobility and other 'ancient' social forces were therefore written off as useless - unless they changed their attitude - while the bourgeoisie would urge the kings to bring in reforms along the lines of free trade, especially inland, ousting the erstwhile privileges. What about the idea of the common good? The common good began to be construed, rather, as social felicity, but as felicity now shorn of any supernatural references and to be guaranteed, moreover, solely by the king's shrewd politics. This is enlightened reformism, already present by the final decades of the seventeenth century. To carry it out, the king needed power, so the debate now centred on the amount of power the king could have: his degree of absolutism.

Another moot point was how far kings needed the support of traditional groups and when this support should be called on; or which types of powers and responsibilities, hitherto denied to the crown, should be returned to the king by the privileged groups. At any rate, whether absolutist king or parliamentary system, the king - or the state, as the case may be - remained the hub of things. From now on it would be increasingly the king's responsibility, together with the government, to define what the common good might be and how it might be achieved.

The eighteenth century saw a spectacular increase in colonial trade, the crucible par excellence of capitalist wealth and therefore the most fertile seedbed of Braudel's legality-stretching profit motive. Colonial trade, however, depended directly on the kings' rules, so it was in essence quite variable. In some countries the king gave more leeway to merchants, while in others a closer watch was kept on them. These different legal scenarios not only produced different economic results, but also engendered different ethical attitudes towards trade, based more on an opportunity-cost basis than on morality. The opportunity cost depended, in this case, on the legal frame.

The legal frame of freedom favoured, logically, a sense of free merchant action vis-à-vis the government, but also a parallel feeling that social problems depended on this government rather than on the merchant. This therefore favoured an ethic of responsibility towards the merchants' own actions and fate, while disregarding those of the rest. In essence it was not a lack of fellow feeling as such; rather a feeling that 
solidarity was not a direct part of their remit. In a legal frame of freedom, solidarity has a cost and self-interest could also be seen as a virtue (Hirschman, 1977).

The monopoly state of affairs, for its part, or the strictest state interventionism, made the profit dependent on the security granted by the privilege in each case. The merchant played less of a managerial role since profit depended not only on economic expertise but also on the overarching law. Moreover, by joining their fates with the government's, merchants also considered that no other responsibility for fellow feeling was incumbent on them, over and above the implicit solidarity of their monopoly-shielded function. Monopoly generates an ethic of dependence on government, an ethic of slackness.

What seems to come to light, therefore - both in countries of greater freedom like England and in monopoly-based economies like Spain - is that merchants now ignored the aspects of fellow feeling that previously - in the Middle Ages - they had taken into account. Fellow feeling - that is, a concern for the poor or the curbing of profit in favour of society as a whole - is an idea that slipped from the minds of most merchants during the eighteenth century, albeit for different reasons and with different consequences. Experience seemed to show, moreover, that greater freedom tended to go hand in hand with greater private profit, so individual interest was construed as an ethical attitude in favour of everyone. This is what happened with the formation of Adam Smith's mercantile society. At this moment, the common good would seem to be the concern of governments only, while merchants were bound only to seek their own interests (Lázaro Cantero, 2002).

The situation had changed. The economy previously subordinated to a higher ethic - that of the common good - had now become, after a stage of emancipation, an independent economy. There was now a clear chasm between common interests and private interests: the king had to look out only for the common interests, and merchants for their private concerns. This is the triumph of individualism that would soon take the form of attacks on the old institutions - the guilds - and the various free-tradehindering privileges of the landlords. Although a liberalization of commercial legislation was desirable, the ethical stance was undermined by the practical lack of concern for the rest after the triumph of self and political interests. This individualism claimed not to be harmful because the common concerns of justice were supposedly dealt with by the king. Soon this would prove not to be the case; a new sort of poverty was brewing, of those sidelined by a mercantilized and dehumanized economic attitude. 


\subsection{BY WAY OF CONCLUSION}

The problem, once more, is not self-seeking per se but, rather, forgetting the rest while looking out for your own. Medieval merchants also looked out for their own interests, but admitted the rightfulness of doing so within a legal and ethical framework. In the eighteenth century, on the contrary, the ideas of reciprocity, or of gift, were no longer catered for by the general tenets of the economy, even though some still guided their lives by them. Subsequent utilitarianism cemented this chasm between the economy and personal business interests on the one hand, and any social concern on the other, which was now the exclusive remit of government. At any rate, the triumph of liberal governments in the nineteenth century hindered the development of social policies, which were not undertaken until much later or were mishandled at the time in the form of workhouses, for example, or the initial banning of trade unions.

\section{REFERENCES}

Aurell, Jaume (ed.) (2002), El Mediterráneo medieval y renacentista, espacio de mercados y de culturas, Pamplona: EUNSA.

Beik, William (1992), Absolutism and Society in Seventeenth-century France, Cambridge, UK: Cambridge University Press.

Bernal, Antonio M. (2005), España, proyecto inacabado: costes/beneficios del Imperio, Madrid: Marcial Pons.

Braudel, Fernand (1985), La dinámica del capitalismo, Madrid: Alianza.

Burke, Peter (1994), The Fabrication of Louis XIV, New Haven, CT: Yale University Press.

Chafuen, Alejandro A. (1986), Christians for Freedom: Late-Scholastic Economics, San Francisco, CA: Ignatius Press.

Clark, Henry C. (1998), 'Commerce, the virtues, and the public sphere in early seventeenth century France', French Historical Studies, 21(3): 415-40.

De Roover, Raymond (1948), Money, Banking and Credit in Medieval Bruges, Cambridge, MA: Harvard University Press.

Deyon, Pierre (1969), Le mercantilisme, Paris: Flammarion.

Duby, George (1978), Les trois ordres ou l'imaginaire du féodalisme, Paris: Gallimard.

Evangelisti, Paolo (2009), 'Il valore di Cristo: l'autocomprensione della comunità política in Francesc Eiximenis', Enrahonar, 42: 65-90.

Faret, Nicolas (1630), L'Honnête Homme ou l'art de plaire à la cour, Lyon: Jean Huguetan.

González Enciso, Agustín (2009), 'Libertad, privilegio y monopolio en la política económica de Floridablanca', Res Publica, 22: 257-77. 
González Enciso, Agustín (2011), El nacimiento del capitalismo en Europa, Pamplona: Eunate.

González Enciso, Agustín (2013), 'La crisis de la función estamental de la nobleza, siglos XVII y XVIII', in Raquel Lázaro Cantero (ed.), De ética y política: conceptos, historia, instituciones, Madrid: Tecnos, pp. 147-77.

Grice-Hutchinson, Margaret (1952), The School of Salamanca: Readings in Spanish Monetary Theory, 1544-1605, Oxford: Oxford University Press.

Groethuysen, Bernard (1981), La formación de la conciencia burguesa en Francia durante el siglo XVIII, Madrid: Fondo de Cultura Económica.

Hirschman, Albert O. (1977), The Passions and the Interests: Political Arguments for Capitalism before its Triumph, Princeton, NJ: Princeton University Press.

Kessler, Amalia D. (2007), A Revolution in Commerce: The Parisian Merchant Court and the Rise of Commercial Society in Eighteenth-Century France, New Haven, CT: Yale University Press.

Lapeyre, Henry (2008), Una familia de mercaderes: los Ruiz, Valladolid: Junta de Castilla y León.

Lázaro Cantero, Raquel (2002), La sociedad comercial en Adam Smith: método, moral, religión, Pamplona: EUNSA.

Le Goff, Jaques (2012), Lo sterco del diavolo: il denaro nel medioevo, Bari: Laterza.

Mitre, Emilio (2013), Ciudades medievales europeas, Madrid: Cátedra.

Monod, Paul K. (2001), El poder de los reyes, Madrid: Alianza.

Murray, James M. (2010), 'Entrepreneurs and entrepreneurship in medieval Europe', in David S. Landes, Joel Mokyr and William J. Baumol (eds), The Invention of Enterprise, Princeton, NJ: Princeton University Press, pp. 88-105.

Origo, Iris (1963), The Merchant of Prato: Daily Life in a Medieval Italian City, London: Penguin Books.

Parker, Geoffrey (1989), The Military Revolution: Military Innovation and the Rise of the West, 1500-1800, Cambridge, UK: Cambridge University Press.

Piettre, André (1955), Les trois âges de l'économie, Paris: Les Editions Ouvrières.

Puigarnau, Alfons (2002), 'Cultura mercantil y devoción mística en la Barcelona del Quinientos', in Jaume Aurell (ed.), El Mediterráneo medieval y renacentista, espacio de mercados y de culturas, Pamplona: EUNSA, pp. 103-41.

Rodríguez Casado, Vicente (1981), Orígenes del capitalismo y del socialismo contemporáneo, Madrid: Espasa Calpe.

Sombart, Werner (1972), El burgués, Madrid: Alianza.

Stark, Rodney (2005), The Victory of Reason: How Christianity Led to Freedom, Capitalism and Western Success, New York: Random House.

Strayer, Joseph R. (1970), On the Medieval Origins of the Modern State, Princeton, NJ: Princeton University Press.

Thompson, Edward P. (1974), 'La economía moral de la multitud en Inglaterra en el siglo XVIII', Revista de Occidente, 133: 54-125.

Vázquez de Prada, Valentín (1999), Historia económica mundial, Pamplona: EUNSA. 